\title{
ACTIVACIÓN ALCALINA DE CENIZAS VOLANTES. ESTUDIO COMPARATIVO ENTRE ACTIVADORES SÓDICOS Y POTÁSICOS
}

\section{ALKALI ACTIVATED FLY ASH BINDERS. A COMPARATIVE STUDY BETWEEN SODIUM AND POTASSIUM ACTIVATORS}

\author{
A. FERNÁNDEZ-JIMÉNEZ (*), A. PALOMO(*), M. CRIADO(*)
}

Recepción/Received: 21-II-05

Aceptación/Accepted: 14-VII-05

\section{RESUMEN}

Este trabajo muestra el efecto de la naturaleza del activador alcalino en el desarrollo microestructural de sistemas de ceniza volante, activados térmica y alcalinamente. Los componentes alcalinos empleados en esta investigación fueron: $\mathrm{NaOH}, \mathrm{KOH}$ $\mathrm{Na}_{2} \mathrm{CO}_{3}, \mathrm{~K}_{2} \mathrm{CO}_{3}$, silicato sódico y silicato potásico. Los resultados obtenidos confirman que el principal producto de reacción del proceso de activación (a través de los sistemas estudiados) es un gel de aluminosilicato alcalino amorfo con estructura tridimensional ya observada en trabajos previos. Se ha demostrado que el tipo de anión y catión involucrado en la reacción de activación de las cenizas no sólo afecta al desarrollo microstructural de los sistemas sino también a la relación Si/A del gel prezeolítico. Por ejemplo, en presencia de silicatos solubles el contenido de $\mathrm{Si}$ en la estructura final aumenta notablemente ( $\mathrm{Si} / \mathrm{Al}=2,7-3)$. Sin embargo la presencia de iones carbonato juega un papel diferente: la formación de carbonatos/ bicarbonatos de sodio o potasio acidifica el sistema y, por consiguiente, la velocidad de reacción es considerablemente menor. Finalmente, es evidente que, cuando todas las condiciones experimentales son iguales, el sodio tiene una capacidad mayor que el potasio para acelerar las reacciones de fraguado y endureciendo de las cenizas volantes y para estimular el crecimiento de zeolitas cristalinas (productos secundarios). En general puede afirmarse que los iones $\mathrm{OH}^{-}$actúan como un catalizador de la reacción, mientras que el metal alcalino $\left(\mathrm{M}^{+}\right)$actúa como un elemento formador de la estructura.

Palabras clave: ceniza volante, activación alcalina, sodio, potasio, materiales cementantes.

\section{INTRODUCCIÓN}

La activación alcalina de cenizas volantes es un proceso químico por el que el componente vítreo de este

\section{SUMMARY}

This paper shows the effect of the nature of some alkaline activators in the microstructural development of thermal-alkali activated fly ash systems. The alkaline compounds employed in this investigation were: $\mathrm{NaOH}, \mathrm{KOH}, \mathrm{Na}_{2} \mathrm{CO}_{3} \mathrm{~K}_{2} \mathrm{CO}_{3}$ sodium silicate and potassium silicate. Results confirm that the main reaction product of the activation process (throughout the studied systems) is the amorphous alkaline aluminosilicate gel with a three-dimensional structure already observed in earlier research. It has been proved that the type of anion and cation involved in the activation reaction of the ashes not only affects the microstructural development of the systems but the Si/Al ratio of that prezeolitic gel too. For example, in the presence of soluble silicate ions the content of Si in the final structure is notably increased (Si/Al=2.7-3); however carbonate ions play a different role since the formation of Sodium or Potassium carbonate/ bicarbonate acidifies the system and consequently the reaction rate is considerably slowed. Finally, it is evident that, when all experimental conditions are equal, sodium has a greater capacity than potassium to accelerate the setting and hardening reactions of fly ash and also to stimulate the growth of certain zeolitic crystals (reaction by-products). In general it can be affirmed that $\mathrm{OH}$ ion acts as a reaction catalyst, and the alkaline metal $\left(\mathrm{M}^{+}\right)$acts as a structure-forming element.

Keywords: fly ash, alkali activation, sodium, potassium, binding materials.

$\left(^{*}\right)$ (Instituto de Ciencias de la Construcción Eduardo Torroja (CSIC). Madrid (ESPAÑA).

Persona de contacto/Corresponding author. palomo@ietcc.csic.es (A. Palomo).

\section{INTRODUCTION}

Alkali activation of fly ashes is a chemical process by which the glassy component of this industrial by-product 
subproducto industrial es transformado en un material cementoso compacto (también denominado "geocement", "geopolymer" o "hydroceramic") caracterizado por sus excelentes propiedades adherentes, desarrollo de resistencias mecánicas y de otras propiedades atribuidas a las cerámicas tradicionales (suavidad superficial, vidrio, lustre) (1-7). También debe mencionarse que la mezcla fresca (pasta formada por ceniza volante y disolución alcalina) es trabajable con bajas relaciones líquido/sólido y fragua en cortos espacios de tiempo $(8,9)$.

Mineralógicamente hablando, los productos formados en la reacción son dependientes de la disolución inicial en la que la ceniza es disuelta y del grado de condensación de las especies iónicas formadas. En todos los casos, el principal producto de la reacción es un gel del aiuminosilicato alcalino (amorfo a DRX). En su microestructura, el Si y el Al se distribuyen al azar en las tres direcciones espaciales; las cavidades que quedan son lo suficientemente grandes para acomodar los cationes alcalinos que compensan las cargas eléctricas del sistema. En este proceso, el gel tixotrópico inicialmente formado polimeriza progresivamente y se enriquece en sílice $(10,11)$.

Desde el punto de vista microscópico, tanto la morfología como la distribución de fases que componen este material son elementos susceptibles de cambio en función de las variables relacionadas con las condiciones del trabajo experimental: tiempo y temperatura de curado, tipo de activador alcalino, etc. En cualquier caso, las matrices desarrolladas casi siempre evolucionan hacia un sólido compacto (en períodos de tiempo relativamente cortos) que se caracteriza, entre otras cosas, por contener un moderado número de partículas de ceniza volante, que no han logrado reaccionar (12-13).

En trabajos previos (13-14), los autores de la presente investigación ya observaron que la microestructura que puede desarrollar este tipo de material conglomerante, efectivamente, puede variar dependiendo del tipo de anión presente en la disolución alcalina utilizada durante el proceso de activación de las cenizas; de manera que, por ejemplo, un incremento en la cantidad de silicatos en el sistema (incorporados en forma de silicatos solubles) provoca una reducción del volumen de poros en el sistema (el producto final es más denso y más compacto) pero también la aparición de microfisuras; o que la presencia de carbonatos tiene una influencia notable en la cinética de las reacciones, retrasando el normal desarrollo mecánico-resistente.

Muchas menos, sin embargo, han sido las investigaciones realizadas en el campo de la activación alcalina de las cenizas volantes en las que se profundiza en el efecto que ejercen los diferentes cationes alcalinos (formadores de red) en el desarrollo mecánico-resistente y microestructural de los materiales sintetizados.

Es por ello que el principal objetivo planteado en el presente trabajo es el de comparar el efecto que ejercen diferentes compuestos de sodio y potasio, tanto en el proceso reactivo de las cenizas como en la mineralogía de los productos finales. is transformed into a compact cementitious material (sometimes called either "geocement", "geopolymer" or "hydroceramic") identified by its excellent binding capabilities, excellent mechanical strength development and various other properties specifically attributed to traditional ceramics (smoothness, glassiness and lustre) $(1-7)$. It should also be mentioned that the fresh mixture (paste formed by fly ash and the alkaline solution) is readily workable and provides low liquid/solid ratios and short setting times $(8,9)$.

Mineralogically speaking, the products formed in the reacting system are dependent on the initial solution in which the fly ash is dissolved and on the condensation level of the ionic species formed. In any case, the major reaction product is always an alkaline aluminosilicate gel (amorphous to XRD). Si and Al are distributed at random in the three spatial directions in its microstructure although cavities are left that are large enough to accommodate the alkaline cations assigned to compensate the electrical charge generated. In this process, the initially formed thixotropic gel is progressively polymerised and enriched in silicon $(10,11)$.

From a microscopic point of view, both the morphology and the phase distribution of this material are elements susceptible to change according to the variables in relation to the experimental working conditions: time and curing temperature, type of alkaline activator, etc. In any case, the matrixes developed almost always evolve into a compact solid (in relatively short periods of time) that is characterized, among other things, as containing a moderate number of spherical fly ash particles, which have not managed to react (12-13).

In earlier experiments (13-14), the authors of this research had already observed that this type of conglomerate material can develop a microstructure that can in fact change depending on the type of anion present in the alkaline solution used during the ash activation process; so that, for example, an increase in the amount of silicates in the system (incorporated by way of soluble silicates) causes a reduction in the volume of pores within the system (the end product is denser and more compact) but microfissures also appear; or the presence of carbonates has a notable influence in the reaction kinetics and slows down the normal mechanical strength development.

However there has been far less research carried out in the field of alkali activation of fly ash, which looks deeply into the effect that different alkaline cations exert (network forming) in the mechanical strength and microstructural development of synthesized materials.

For this reason the main objective of this paper concerns comparing the effect that different sodium and potassium compounds exert not only during the reaction process between ash and alkalis but also in the mineralogy of the end products. 


\section{EXPERIMENTAL}

En esta investigación se utilizó una ceniza española (tipo $F$ de acuerdo con la clasificación ASTM) procedente de la combustión de carbón de antracita. En la Tabla 1 se muestra su análisis químico, no obstante, una completa información sobre las características de esta ceniza (ceniza volante " $C P^{\prime}$ ) puede ser encontrada en trabajos previos (15). En cualquier caso, es importante remarcar que esta ceniza contiene aproximadamente un $90 \%$ de partículas de un tamaño inferior a $45 \mu \mathrm{m}$ y un $50 \%$ menor de $10 \mu \mathrm{m}$.

Seis activadores diferentes (disoluciones alcalinas) fueron estudiados: $\mathrm{NaOH}, \mathrm{KOH}$, silicato sódico, silicato potásico, carbonato sódico y carbonato potásico. La concentración de estos compuestos en la disolución acuosa se muestra en la Tabla 2. Los productos usados para preparar las disoluciones activadoras fueron reactivos de

\section{EXPERIMENTAL}

A spanish fly ash (type F fly ash according to ASTM classification) produced by the combustion of an anthracitic soft coal has been used in this investigation. Its chemical analysis is given in Table 1, although complete information on the characteristics of this fly ash (fly ash " $C P$ ") can be found in a previous paper (15). In any case it is important to mention that this fly ash contains approximately $90 \%$ of particles smaller than $45 \mu \mathrm{m}$ and $50 \%$ smaller than $10 \mu \mathrm{m}$.

Six different activators (alkaline solutions) were investigated: $\mathrm{NaOH}, \mathrm{KOH}$, sodium silicate, potassium silicate, sodium carbonate and potassium carbonate. The concentration of these compounds in the mixing water is given in Table 2. The products used to prepare the activator solutions were laboratory analysis reagents: $98 \%$ pure

TABLA 1/ TABLE 1

Análisis químico de la ceniza volante empleada (\% en peso)

Chemical analysis of the fly ash used (\% wt.)

\begin{tabular}{|c|c|c|c|c|c|c|c|c|c|c|c|}
\hline L.O.I. & $\begin{array}{c}\text { Insol } \\
.\end{array}$ & $\mathrm{SiO}_{2}$ & $\mathrm{Al}_{2} \mathrm{O}_{3}$ & $\mathrm{Fe}_{2} \mathrm{O}_{3}$ & $\mathrm{CaO}$ & $\mathrm{MgO}$ & $\mathrm{SO}_{3}$ & $\mathrm{~K}_{2} \mathrm{O}$ & $\begin{array}{c}\mathrm{Na}_{2} \\
0\end{array}$ & $\begin{array}{c}\mathrm{TiO}_{2} \\
\text { Total }\end{array}$ & \\
\hline 3.59 & 0.32 & 53.09 & 24.80 & 8.01 & 2.44 & 1.94 & 0.23 & 3.78 & 0.73 & 1.07 & 100.00 \\
\hline
\end{tabular}

L.O.I = pérdida al fuego; Insol. = Residuo Insoluble

L.O.I. = Loss on ignition; Insol. = Insoluble Residue.

TABLA 2/ TABLE 2

Composición de las disoluciones activadoras Composition of the activator solutions.

\begin{tabular}{|c|c|c|c|c|c|c|}
\hline $\begin{array}{l}\text { Disolución activadora } \\
\text { Activator solution }\end{array}$ & $\begin{array}{c}{\left[\mathrm{Na}_{2} \mathrm{O}\right]} \\
\%\end{array}$ & $\begin{array}{c}{\left[\mathrm{K}_{2} \mathrm{O}\right]} \\
\%\end{array}$ & $\begin{array}{c}{\left[\mathrm{SiO}_{2}\right]} \\
\%\end{array}$ & $\begin{array}{c}{\left[\mathrm{CO}_{3}^{2-}\right]} \\
\%\end{array}$ & $\begin{array}{l}\text { Densidad } \\
\text { Density } \\
\left(\mathrm{gr} / \mathrm{cm}^{3}\right)\end{array}$ & $\begin{array}{l}{\left[\mathrm{OH}^{-}\right]^{1}} \\
(\mathrm{Mol} / \mathrm{I})\end{array}$ \\
\hline Disolución A /Solution A: $\mathrm{NaOH}$ & 19.525 & ---- & $-\cdots$ & $-\cdots$ & 1.27 & 8 \\
\hline $\begin{array}{l}\text { Disolución } \mathrm{B} / \text { Solution } \mathrm{B}: \mathrm{NaOH}+ \\
\text { silicato sódico } \mathrm{NaOH}+\text { Sodium silicate }\end{array}$ & 21.025 & $-\cdots$ & 3.050 & ---- & 1.33 & 10 \\
\hline $\begin{array}{l}\text { Disolución C /Solution: } \mathrm{NaOH}+ \\
\text { carbonato sódico } \mathrm{NaOH}+\text { Sodium } \\
\text { carbonate }\end{array}$ & 20.375 & $-\cdots--$ & $-\cdots--$ & 14.150 & 1.27 & 2 \\
\hline Disolución D / Solution D: $\mathrm{KOH}$ & $-\cdots$ & 30.800 & $-\cdots$ & ----- & 1.30 & 8.5 \\
\hline $\begin{array}{l}\text { Disolución } \mathrm{E} / \text { Solution E: } \mathrm{KOH}+\text { silicato } \\
\text { potásico } \mathrm{KOH}+\text { Potassium silicate }\end{array}$ & $\begin{array}{c}---- \\
\end{array}$ & 31.225 & 3.525 & ---- & 1.36 & 10 \\
\hline $\begin{array}{l}\text { Disolución } \mathrm{F} \text { /Solution F: } \mathrm{KOH}+ \\
\text { carbonato potásico } \mathrm{KOH}+\text { Potassium } \\
\text { carbonate }\end{array}$ & $-\cdots$ & 31.500 & $-\cdots--$ & 10.850 & 1.28 & 3.5 \\
\hline
\end{tabular}

${ }^{1}\left[\mathrm{OH}^{-}\right]$del hidróxido alcalino $(\mathrm{NaOH} \circ \mathrm{KOH})$.

${ }^{1} \mathrm{COH} 7$ from alkali hudroxide $(\mathrm{NaOH}$ or $\mathrm{KOH})$. 
laboratorio para análisis: $\mathrm{NaOH}$ en forma de lentejas de una pureza del $98 \%$; silicato sódico $\left(8,2 \% \mathrm{Na}_{2} \mathrm{O}, 27 \%\right.$ $\mathrm{SiO}_{2}$ y $64,8 \% \mathrm{H}_{2} \mathrm{O}$ ) con una densidad de $1,38 \mathrm{~g} / \mathrm{cc}$; carbonato sódico anhidro de una pureza del $99,8 \% ; \mathrm{KOH}$ en forma de lentejas de una pureza del $85 \%$; silicato potásico $\left(10,5 \% \mathrm{~K}_{2} \mathrm{O}, 23,5 \% \mathrm{SiO}_{2}\right.$ y $\left.66 \% \mathrm{H}_{2} \mathrm{O}\right)$ con una densidad de $1,32 \mathrm{~g} /$ cc y carbonato potásico de una pureza del $99,8 \%$. Todos los reactivos fueron suministrados por PANREAC, S. A.

Las pastas se prepararon mezclando la ceniza volante con las diferentes disoluciones activadoras (disoluciones A, B, C, D, E y F). La relación "solución activadora/ceniza" fue siempre constante e igual a 0,4 en masa. Las muestras de pasta se introdujeron en el interior de unas bolsas de plástico (siempre cerradas) que, a su vez, se guardaron en el interior de una estufa a una temperatura de $85^{\circ} \mathrm{C}$, durante 20 horas (una serie de muestras) y 7 días (otra serie). En todo momento se mantuvieron unas condiciones de humedad del $99 \%$.

Transcurrido el tiempo de curado térmico se hizo una caracterización mineralógica y microestructural de los distintos materiales producidos mediante DRX y SEM/EDX. El difractómetro utilizado en el presente trabajo fue un PHILIPS PW-LINK y el microscopio electrónico un JEOL 5400 con sistema de microanálisis EDX OXFORD-LINK.

\section{RESULTADOS}

\subsection{X-Ray Diffraction}

Los resultados del análisis mineralógico (por DRX) de los materiales objeto de estudio se resumen en la Figura 1.

En los cuatro grupos de difractogramas que conforman la Figura1 (a, b, c y d) se incluye siempre el difractograma correspondiente a la ceniza volante de partida. Dicha ceniza está constituida principalmente por una fase vítrea (ver halo registrado entre $2 \theta=20-35^{\circ}$ ) y por algunas fases cristalinas de carácter minoritario (cuarzo, mullita).

Por otra parte, la totalidad de los difractogramas de dicha Figura 1 (correspondientes a la ceniza activada con las diferentes disoluciones y térmicamente curada a diferentes tiempos) revelan que como consecuencia del proceso de activación de la ceniza, el halo atribuido a la fase vítrea de ésta se desplaza ligeramente hacia valores más altos de $2 q$; lo que indica que el proceso químico al que se sometieron las cenizas volantes (llevado a cabo con el objetivo de producir un sistema cementante) se desarrolla de forma similar (cualitativamente hablando), tanto con los compuestos de sodio, como con los compuestos de potasio (con todos los activadores utilizados en la investigación). En todos los sistemas se produce la formación de un gel de aluminosilicato (precursor zeolítico) descrito en trabajos previos $(1,4,10,11)$.

También se observa, en la práctica totalidad de los difractogramas de la Figura 1, la presencia de otras fases cristalinas no presentes en la ceniza original (la cantidad y el tipo de fase cristalina detectada depende del activador empleado y del tiempo de curado).
$\mathrm{NaOH}$ pellets; sodium silicate ( $8.2 \% \mathrm{Na}_{2} \mathrm{O}, 27 \% \mathrm{SiO}_{2}$ and $64.8 \% \mathrm{H}_{2} \mathrm{O}$ ) with a density of $1.38 \mathrm{~g} / \mathrm{CC} ; 99.8 \%$ pure anhydrous sodium carbonate; $85 \%$ pure $\mathrm{KOH}$ pellets; potassium silicate $\left(10.5 \% \mathrm{~K}_{2} \mathrm{O}, 23.5 \% \mathrm{SiO}_{2}\right.$ and $\left.66 \% \mathrm{H}_{2} \mathrm{O}\right)$ with a density of $1.32 \mathrm{~g} / \mathrm{CC}$ and $99.8 \%$ pure potassium carbonate. PANREAC, S. A. supplied all the reagents.

Pastes were prepared by mixing fly ash with different activator solutions (solutions $A, B, C, D, E$ and $F$ ). The "activator solution/ash" ratio was always constant and equivalent to 0.4 in mass. Paste samples were put into plastic bags (that always remained closed) and in turn these were placed in a laboratory oven at a temperature of $85^{\circ} \mathrm{C}$, for 20 hours (one series of samples) and for 7 days (another series). A humidity of $99 \%$ was maintained at all times.

Following the thermal curing time a mineralogical and microstructural characterization of the different materials was carried out by using XRD and SEM/EDX. The diffractometer used for this work was a PHILIPS PW-LINK and the Electron Microscope a JEOL 5400 with EDX EXFORD-LINK microanalysis system.

\section{RESULTS}

\subsection{X-Ray Diffraction}

The results of the mineralogical analysis (by XRD) of the materials that are the object of this research are summarized in Figure 1.

The four groups of diffractogrammes given in Figure 1 $(a, b, c$ and d) always include the diffractogramme corresponding to the initial fly ash. This ash mainly comprises a glassy phase (see the "hump" recorded between $2 \theta=20-35^{\circ}$ ) and for some minority crystalline phases (quartz, mullite).

On the other hand all the diffractogrammes in Figure 1 (corresponding to the ash activated with different solutions and thermally treated for different periods) reveal that, due to the ash activation process, the "hump" attributed to its glassy phase shifts slightly towards greater $2 \theta$ values. This indicates that the chemical process to which the fly ash was subjected (undertaken in order to produce a cementitious system), develops in a similar way (qualitatively speaking) not only with sodium compounds but also with potassium compounds (with all the activators used in the investigation). Every system produces alkaline aluminosilicate gel (zeolite precursors) described in earlier works $(1,5,10,11)$.

From practically all the diffractogrammes in Figure 1 the presence of other crystalline phases not present in the original ash can also be observed (the amount and type of crystalline phase detected depends on the activator used and on the curing time). 

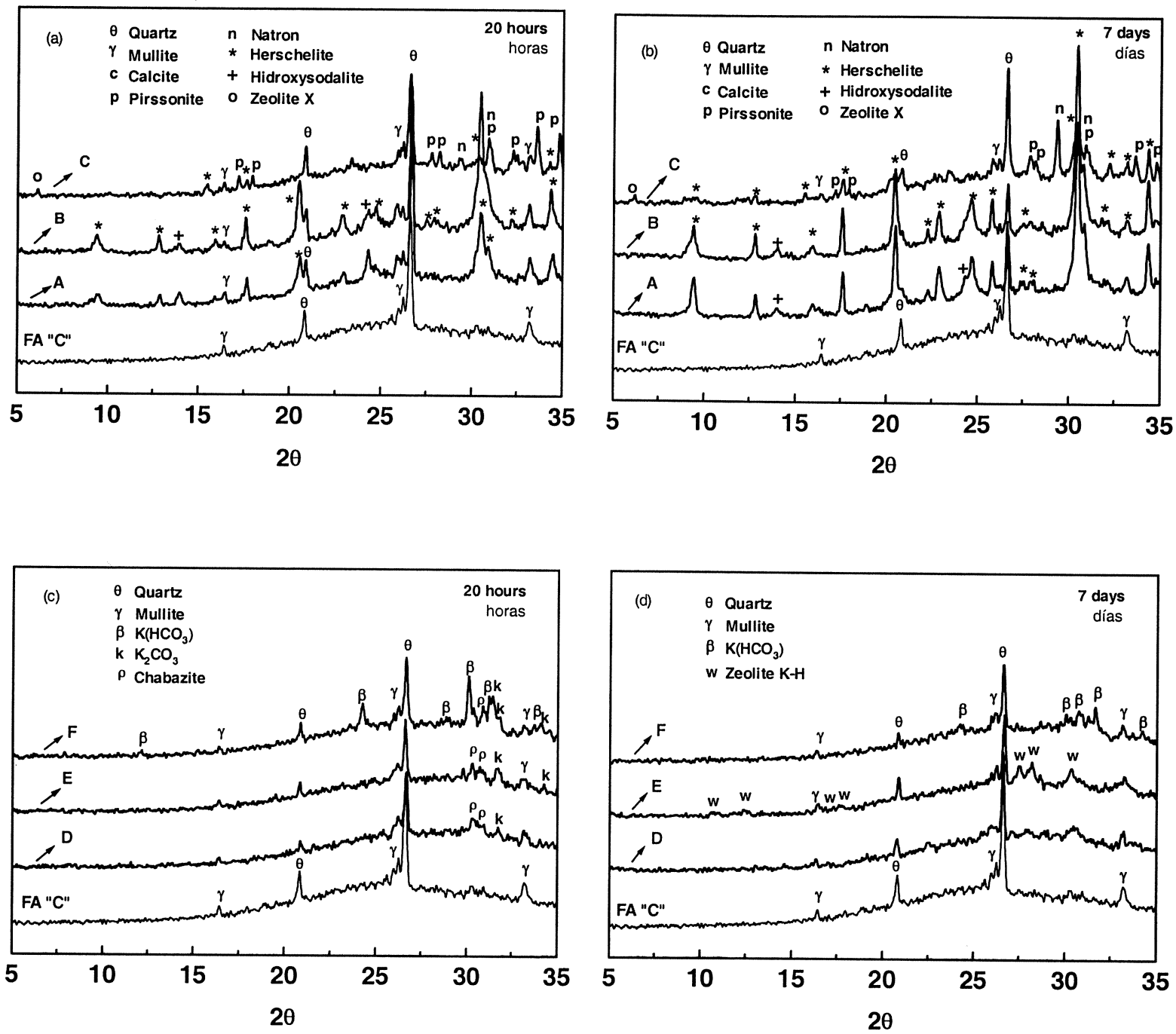

Figura 1.- (a) y (b): Ceniza volante activada alcalinamente con las disoluciones A, B y C [(a) 20 horas a $85^{\circ} \mathrm{C}$ y (b) 7 días a $\left.85{ }^{\circ} \mathrm{C}\right]$; (c) y (d): ceniza volante activada con las disoluciones $D, E$ y $F_{\text {, }}$ (c) 20 horas a $85^{\circ} \mathrm{C}$ y (d) 7 días a $\left.85^{\circ} \mathrm{C}\right]$.

Figure 1. - Alkali activated fly ash activated with solution A, B and C for (a) 20 hours at $85^{\circ} \mathrm{C}$ and (b) 7 days at $85^{\circ} \mathrm{C}$; and alkali activated fly ash «C» activated with solution D, E and $F$ for (c) 20 hours at $85^{\circ} \mathrm{C}$ and (d) 7 days at $85^{\circ} \mathrm{C}$.

Los difractogramas de las cenizas activadas con las disoluciones A y B (ver Figura 1) presentan algunos picos intensos asociados a la presencia de zeolitas del tipo de la hydroxisodalita $\left(\mathrm{Na}_{4} \mathrm{Al}_{3} \mathrm{Si}_{3} \mathrm{O}_{12} \mathrm{OH}\right)$ y de la chabacita-Na también llamada herschelita ( $\left.\mathrm{NaAlSi}_{2} \mathrm{O}_{6} \cdot \mathrm{H}_{2} \mathrm{O}\right)$. La intensidad de los picos de la hydroxisodalita se mantiene constante con el tiempo y en niveles que son propios de la existencia de muy pequeñas proporciones de esta zeolita y que sugieren que este producto se forma sólo en los primeros momentos de la reacción; cuando, de forma puntual, se dan las condiciones adecuadas para su precipitación. Por otra parte, la intensidad de los picos de la herschelita aumenta significativamente con el tiempo de curado térmico, lo cual se puede interpretar en el sentido de que la composición mineralógica más estable del gel cementante prezeolítico, en estos sistemas, es una composición del tipo de la da la herschelita (16).

El difractograma de la ceniza activada con la disolución C, sin embargo, muestra una evolución muy diferente:
The diffractogrammes of the ash activated with solutions $A$ and $B$ (see Figure 1) present some intense peaks associated with the presence of zeolites of the hydroxysodalite ( $\mathrm{Na}_{4} \mathrm{Al}_{3} \mathrm{Si}_{3} \mathrm{O}_{12} \mathrm{OH}$ ) and chabazite-Na also called herschelite ( $\mathrm{NaAlSi}_{2} \mathrm{O}_{6}, \mathrm{H}_{2} \mathrm{O}$ ) type. The intensity of the hydroxysodalite peaks remains constant over time and at levels that are specific to the existence of very small proportions of this zeolite and that suggest that this product is only produced in the first moments of the reaction; when adequate conditions are specifically provided for its precipitation. On the other hand the intensity of the Herschelite peaks increases significantly by prolonging the thermal curing along the time. It can be interpreted in the sense that the most stable mineralogical composition of the prezeolitic cementitious gel, in these systems, is a composition of the type provided by herschelite (16).

The diffractogramme of the ash activated with solution $C$, however, shows a very different evolution: only a 
sólo se detecta una muy pequeña cantidad de herschelita (incluso tras 7 días de curado) y una señal en $2 \theta=6.12$ asociada a la formación de la zeolita X. No obstante, en este caso, el hecho más destacable es la abundante presencia de trona (bicarbonato sódico) y calcita $\left(\mathrm{CaCO}_{3}\right)$. Es evidente que el empleo de carbonatos induce una cierta acidificación de estos sistemas que alteran notablemente la evolución de las reacciones (17)

En cuanto a los difractogramas correspondientes a los materiales activados con las disoluciones potásicas (disoluciones D, E y F) [Figura 1(c) y 1(d)] lo más destacable es la muy escasa presencia de fases zeoliticas cristalinas. En el difractograma de la Fig. 1(c), por ejemplo, se puede observar la formación de pequeñas cantidades de cristales zeolíticos del tipo de la chabazita- $\mathrm{K}\left(\mathrm{K}_{2} \mathrm{Al}_{2} \mathrm{SiO}_{6} \cdot \mathrm{H}_{2} \mathrm{O}\right)$. También, en las muestras curadas térmicamente durante 7 días y activadas con la disolución $\mathrm{E}$ se detecta la presencia, en pequeña proporción, de la zeolita $\mathrm{K}-\mathrm{H}$ $\left(\mathrm{K}_{2} \mathrm{Al}_{2} \mathrm{Si}_{4} \mathrm{O}_{12} \cdot \mathrm{H}_{2} \mathrm{O}\right)$. Todo ello sugiere que los materiales obtenidos con las disoluciones potásicas están todavía lejos de alcanzar su estabilidad composicional (18). Finalmente, en presencia de carbonatos (materiales activados con la disolución F) tanto a $20 \mathrm{~h}$ como a 7 días de curado precipita carbonato y bicarbonato potásico.

\subsection{Análisis microscópico por SEM}

En la Figura 2 se muestra una micrografía de la ceniza volante utilizada en este estudio. Este material pulverulento está formado principalmente por esferas compactas de diferentes tamaños, con una textura lisa y regular. En las Figuras 3, 4, 5 y 6 se muestran los resultados del estudio llevado a cabo por la técnica de microscópica electrónica. En la Tabla 3, además, se detallan los microanálisis (relacion $\mathrm{Si} / \mathrm{Al}$ ) de los mismos materiales estudiados.

\section{Materiales activados con sodio}

En la Figura 3 se muestran algunas características morfológicas y microestructurales de las cenizas activadas con la disolución $\boldsymbol{A}$ y curadas térmicamente durante $20 \mathrm{~h}$ y 7 días. En las micrografías que componen dicha Figura 3 , junto a las esferas de ceniza sin reaccionar se very small amount of Herschelite is detected (even after 7 days cure) and also some traces of zeolites (see signal in $2 \theta=6.12)$. Nevertheless in this case the most outstanding fact is the abundance of calcite $\left(\mathrm{CaNa}_{2}\left(\mathrm{CO}_{3}\right)_{2}\left(\mathrm{H}_{2} \mathrm{O}\right)_{2}\right)$ and natron (sodic bicarbonate). It is evident that using carbonates induces a certain acidification of these systems that notably alters the evolution of the reactions (17).

As for the diffractogrammes corresponding to the materials activated with the Potassium solutions (solutions D, E and F) [Figure 1(c) and 1(d)] what stands out most is the very limited presence of crystalline zeolitic phases. In the diffractogramme of Figure 1 (c), for example, the formation can be observed of small quantities of zeolitic crystals of the chabazite type $\left(\mathrm{K}_{2} \mathrm{Al} / \mathrm{SiO}_{6} \cdot \mathrm{H}_{2} \mathrm{O}\right)$. Also, in the samples thermally cured for 7 days and activated with solution $E$ the presence of a small amount of zeolite $\mathrm{K}-\mathrm{H}\left(\mathrm{K} / \mathrm{A} / \mathrm{Si}_{4} \mathrm{O}_{12}\right.$ $\left.\cdot H_{2} \mathrm{O}\right)$ can be detected. All this suggests that the materials obtained with the potassium solutions are still far from reaching their compositional stability (18). Finally, potassium carbonate and bicarbonate are precipitated in the presence of those activating solutions prepared with carbonates (materials activated with solution F) not only after a curing period of 20 hours but also 7 days.

\subsection{Microscopic analysis by SEM}

In Figure 2 a SEM micrograph of the ash used in the present study is shown. Hollow or compact spheres of different sizes, with a smooth and regular texture, form most of the powdered material. Figures 3, 4, 5 and 6 are a summary of the results obtained through the electron microscopy technique. In addition, Table 3 a detail of the microanalysis (Si/Al ratio) of the same materials also plotted.

\section{Sodium activated materials}

Figure 3 shows some morphologic and microstructural characteristics of the ash activated with solution $\boldsymbol{A}$ and thermally cured for 20 hours and 7 days respectively. In the micrographs that comprise Figure 3, next to the

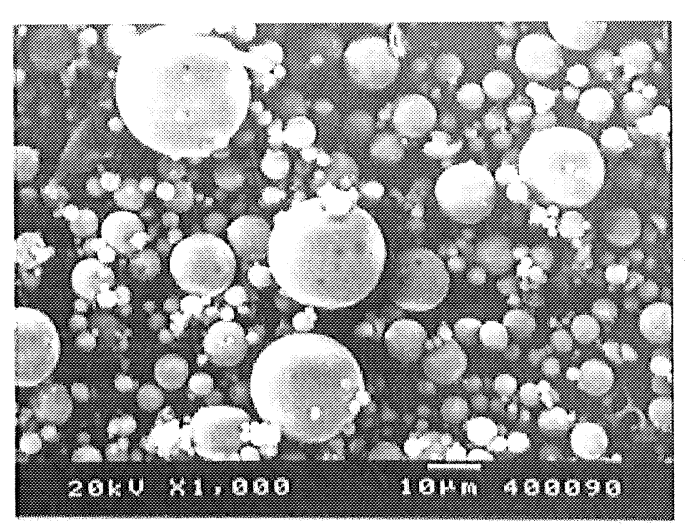

Figura 2.- Ceniza original.

Figure 2.- Original fly ash. 

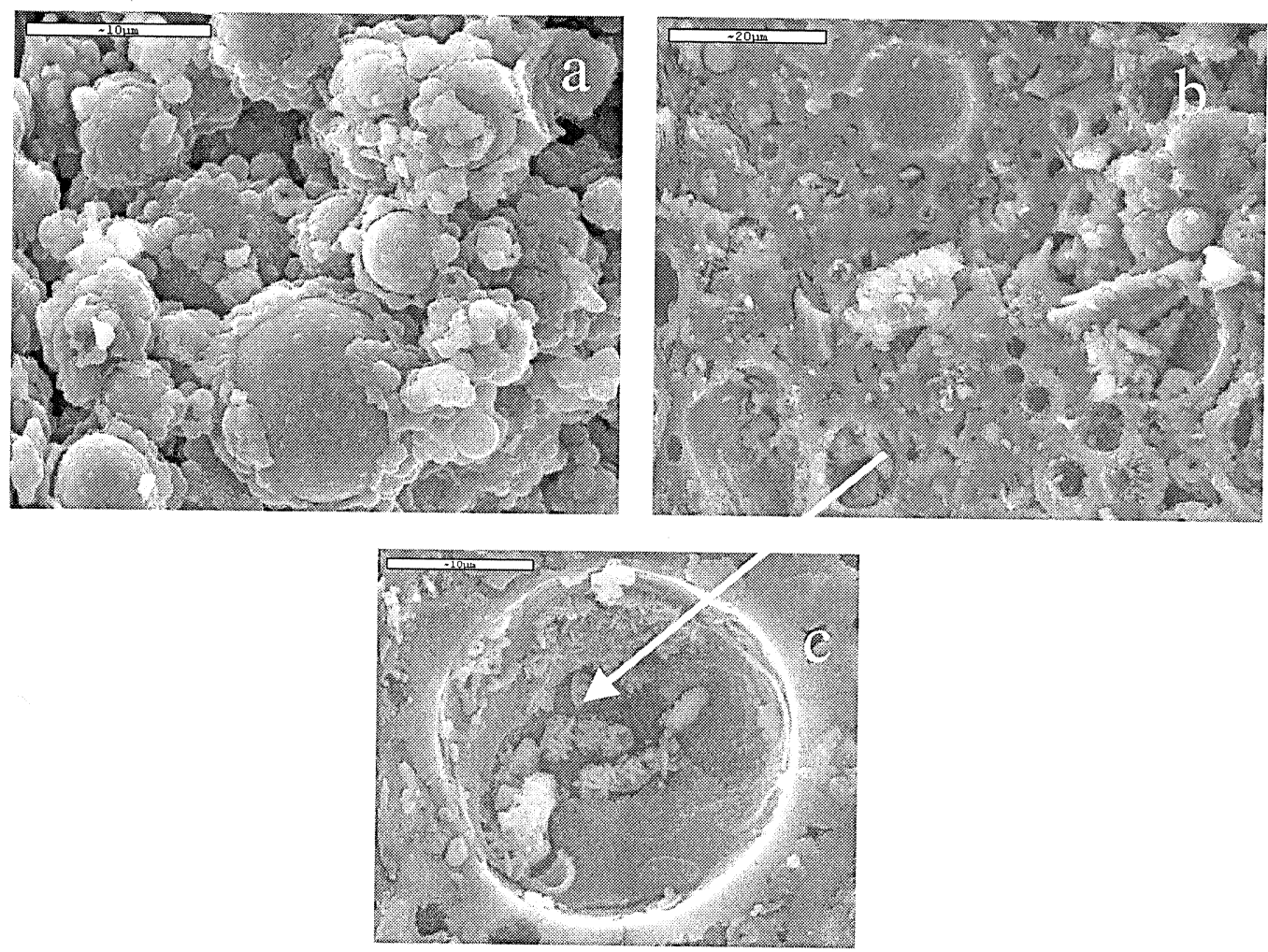

Figura 3.- Ceniza volante activada alcalinamente con la disolución $\mathrm{A}(\mathrm{NaOH} 8 \mathrm{M})$ : (a) $20 \mathrm{~h} \mathrm{a} 85^{\circ} \mathrm{C}$; (b) 7 días a $85^{\circ} \mathrm{C}$; (c) detalle de algunas fases cristalinas (zeolita tipo herschelite).

Figure 3. - Alkali activated fly ash with solution A (NaOH 8M): (a) 20 hours at $85^{\circ} \mathrm{C}$; (b) 7 days at $85^{\circ} \mathrm{C}$; (c) detail of some crystalline phases (herschelite-type zeolite).

observa la presencia del gel de aluminosilicato sódico que forma la matriz cementante y que es el responsable del desarrollo de las propiedades mecánicas del material.

En general, de la Figura 3(a) se puede deducir que en fi activación de las cenizas volantes con la disolución de $\mathrm{NaOH}$ a 20 horas, el grado de reacción alcanzado es moderado; adicionalmente la matriz cementante formada a este tiempo de curado presenta un elevado nivel de porosidad. Otra importante observación a señalar en la Figura 3(a) es que algunas esferas de la ceniza están parcialmente cubiertas de producto de reacción. Ello sugiere que la precipitación de productos de reacción en un corto período de tiempo forma una capa sobre las esferas que aún no han reaccionado, lo cual dificulta su futura activación. Este hecho puede justificar la incompleta reacción de las partículas de ceniza, siempre observada en previas investigaciones en este tipo de sistemas (12-13).

La Figura 3(b) revela que el tiempo de curado térmico es un factor esencial para que la matriz sólida desarrolle consistencia mecánica. Normalmente en el interior de aquellas partículas de ceniza que no han reaccionado completamente o, en los huecos dejados por éstas, se observa la presencia de depósitos cristalinos, que se corresponden con las zeolitas detectadas por DRX. En la Figura 3(c) se presenta un ejemplo de estas fases cristalinas minoritarias; ejempla que se corresponde concretamente con una zeolita del tipo de la herschelite $(12,13)$ con una relación $\mathrm{Si} / \mathrm{Al}=2,09$ y una relación $\mathrm{Na} / \mathrm{Al}=1,02$. unreacted ash spheres the presence of the alkaline aluminosilicate gel can be observed that forms the cementitious matrix and that is responsible for developing high mechanical properties in the material.

In general, from Figure 3(a) it could be deduced that activating the fly ash with a $\mathrm{NaOH}$ solution for 20 hours the degree of reaction achieved by the system is moderate since the cementitious matrix formed at that curing time presents a high level of porosity and some original ash spheres still remain unreacted. Another important observation to be mentioned from Fig. $3(a)$ is that some ash spheres are partially covered with reaction product. It might be suggested that, in a short period of time, the precipitation of the reaction products forms a layer on still unreacted spheres which would difficult its further activation. This phenomenon was already observed in this type of systems in earlier research (12-13).

Figure $3(b)$ reveals that the time of thermal curing is an essential factor in the alkaline activation of fly ashes so that the solid matrix can develop mechanical consistency. Normally inside the ash particles that have not reacted completely, or in the hollows left by them, the presence of crystalline deposits can be observed that correspond to the Zeolite detected by XRD. Figure 3(c) presents an example of these crystalline phases; an example that corresponds specifically to a Herschelite-type zeolite with a Si $/$ Al ratio $=2.09$ and a $\mathrm{Na} / \mathrm{Al}$ ratio $=1.02(12,13)$. 
En la Figura 4 se muestran algunas de las características microscópicas de las pastas activadas con la disolución $\boldsymbol{B}$. El material resultante de este proceso de activación es muy compacto, no presenta casi poros, incluso a las 20 horas de curado térmico. Los productos de reacción forman una superficie continua similar a una monocapa de un fluido viscoso repentinamente congelado (como un vidrio), en lugar de un grupo de partículas individuales que precipitan al azar en el sistema (como un material cementante tradicional). El análisis de EDX confirma que esta matriz tiene una relación Si/Al más alta que la matriz activada con la disolución A (ver Tabla 3). También, en este caso, la incorporación de Si a la matriz cementosa se incrementa con el tiempo de la reacción. En resumen, parece ser que la adición de waterglass a la disolución activante refuerza el proceso de condensación de las especies iónicas del sistema debido a una elevada concentración de iones $\mathrm{OH}^{-}$y a la gran cantidad de silicatos solubles (19). En este caso, el efecto del tiempo de curado térmico (20 horas o 7 días en las condiciones experimentales de esta investigación) no afecta muy significativamente al desarrollo microestructural del material ( $y$, por lo tanto, al desarrollo mecánico-resistente) como en el caso de la activación con la disolución A. En la Figura 4(b) se observa, además, la presencia de cristales zeoliticos bien formados con una composición similar a la de la herschelita (Si/Al=2,17 y $\mathrm{Na} / \mathrm{Al}=0,97)$.

En la Figura 5 pueden observarse las características morfológicas de la ceniza volante activada con la disolución C. Este material es el más poroso de los hasta ahora estudiados [Figura 5(a)]; de hecho, tanto a $20 \mathrm{~h}$ como a 7 días de curado térmico se detecta la presencia de una gran cantidad de partículas de ceniza volante sin reaccionar. El principal producto de reacción a $20 \mathrm{~h}$ presenta una relación Si/Al de 1,83 y Na/Al de 1,2. A 7 días estos valores se incrementan hasta 1,99 y 1,23 respectivamente. En este caso, es importante señalar la formación de una cierta cantidad de seudo-cristales de herschelita (ver Figura 5(b), P1 y P2). El bajo nivel de cristalinidad es confirmado por los resultados obtenidos por DRX, donde la intensidad de los picos asociados a esta herchelita es
In Figure 4 some microscopic characteristics of pastes activated with solution $B$ are shown. What results from this activation process is a very compact material with almost no pores even after only 20 hours of thermal curing. The superficial continuity of the reaction product appears like a monolayer of a suddenly frozen viscous fluid (like glass), instead of a group of individual particles randomly precipitating in the system (like a traditional cementitious material). EDX analysis confirms that this matrix has a higher Si/Al ratio than the matrix activated with solution A (see Table 3). Also in this case the Si content increases with the reaction time. In summary, it seems that the addition of waterglass to the activating solution enhances the condensation process of the ionic species at the system as a media is produced with a high concentration of $\mathrm{OH}$ and a large amount of soluble silicates (19). Therefore in this case, the effect of the thermal curing period (20 hours or 7 days in the experimental conditions of this investigation) does not notably affect the microstructural development of the material (and therefore the mechanical strength development) as in the case of the activation with solution A. Figure $4(b)$ also shows the presence of well-formed zeolitic crystals with a composition similar to that of herschelite $(S i / A /=2.17$ and $\mathrm{Na} / A /=0.97)$.

In Figure 5 the morphological characteristics of the fly ash activated with solution $\boldsymbol{C}$ can be observed. This material is the most porous one among those studied [Fig. 5(a)]; in fact after not only 20 hours but also 7 days of thermal curing, the presence of a large amount of non-reacting fly ash particles is detected. The main reaction product presents at $20 \mathrm{~h}$ a Si/Al ratio of 1.83 and a $\mathrm{Na} / \mathrm{Al}$ ratio of 1.2. At 7 days these values respectively increase until 1.99 and 1.23. In this case, it is important to remark the formation of a certain amount of pseudo-crystals of herschelite (see Figure 5(b), P1 and P2). This low level of crytallinity is confirmed by the results obtained through $X R D$, where the intensity of the peaks associated to the herchelite is low (see Figure 1). The presence of
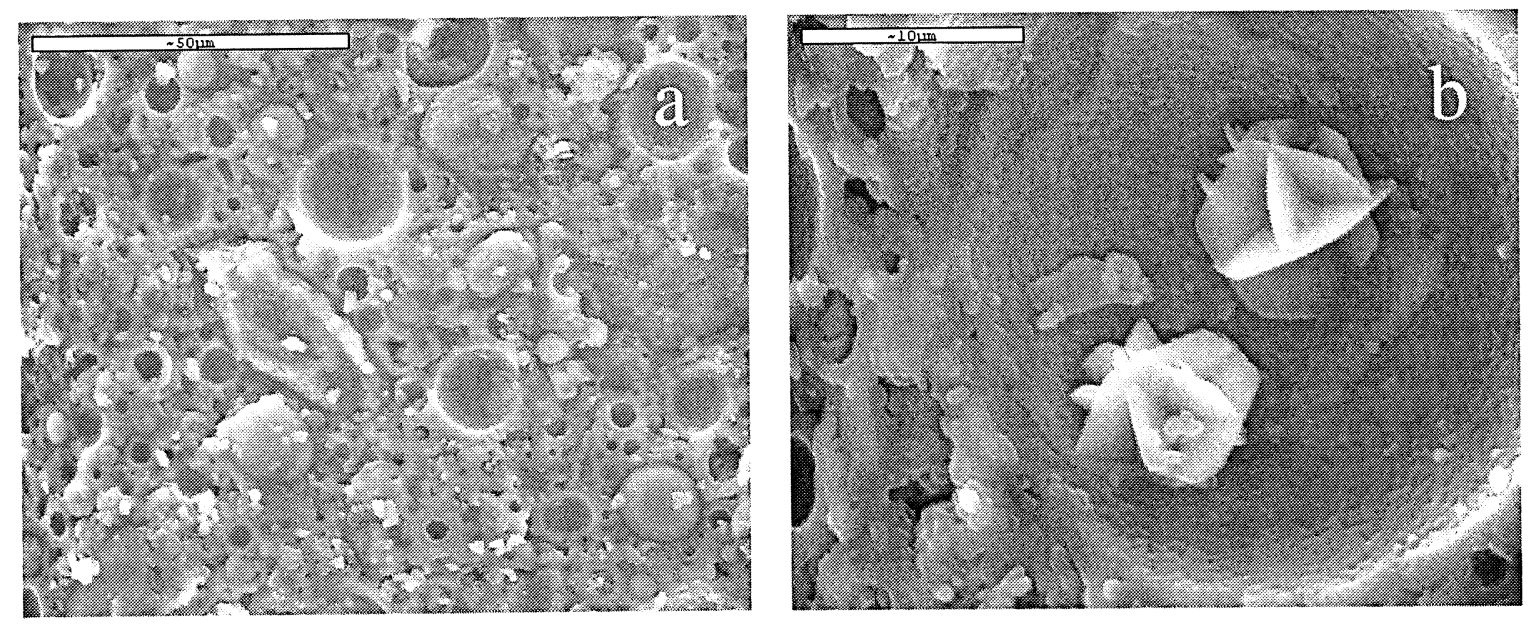

Figura 4.- Ceniza activada alcalinamente con la disolución $\mathrm{B}\left(\mathrm{NaOH} 10 \mathrm{M}+15 \%\right.$ silicato sódico): (a) $20 \mathrm{~h}$ a $85^{\circ} \mathrm{C}$; (b) 7 días a $85^{\circ} \mathrm{C}$.

Figure 4. - Alkali activated fly ash with solution B ( $\mathrm{NaOH} 10 \mathrm{M}+15 \%$ sodium silicate): (a) 20 hours at $85^{\circ} \mathrm{C}$; (b) 7 days at $85^{\circ} \mathrm{C}$. 

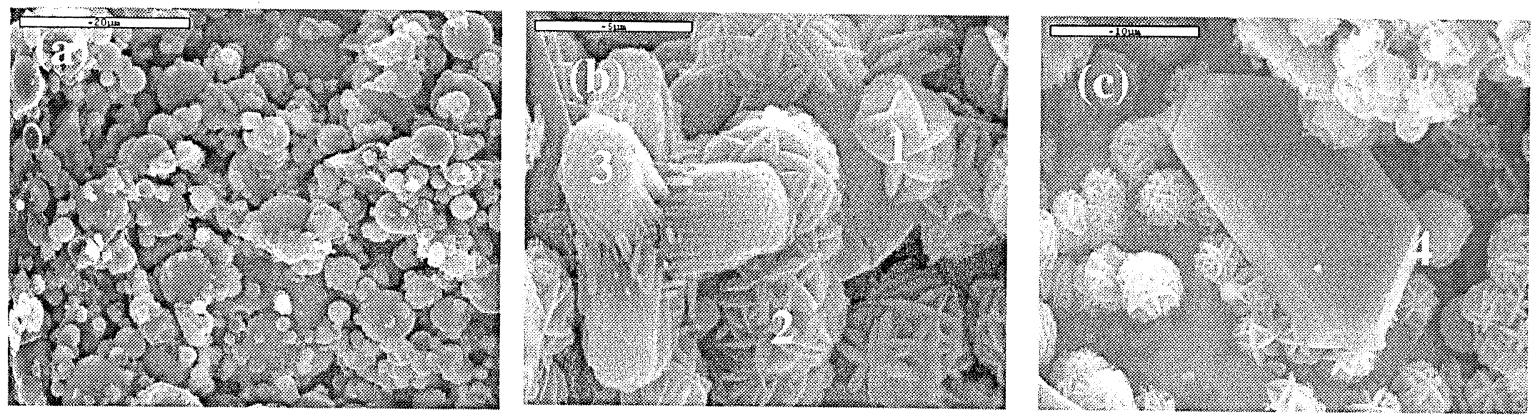

Figura 5.- Ceniza volante activada alcalinamente con la disolucion $\mathrm{C}\left(\mathrm{NaOH} 2 \mathrm{M}+10 \% \mathrm{Na}_{2} \mathrm{CO}_{3}\right.$ en masa con respecto al contenido de ceniza) (a) visión general $20 \mathrm{~h}$ a $85^{\circ} \mathrm{C}$; (b) y (c) 7 días de curado térmico a $85^{\circ} \mathrm{C}$; P1 y P2 pseudo-cristales de herschelita; P3 cristales ortorrómbicos en forma de bastón; P4 cristales poliédricos de carbonatos.

Figure 5. - Alkali activated fly ash with solution $\mathrm{C}\left(\mathrm{NaOH} 2 \mathrm{M}+10 \% \mathrm{Na}_{2} \mathrm{CO}_{3}\right.$ in mass with respect to the fly ash content). (a) general view $20 \mathrm{~h}$ at $85^{\circ} \mathrm{C} ;(\mathrm{b})$ and (c): 7 days of thermal curing at $85^{\circ} \mathrm{C}$; P1 and P2 pseudo-crystals of herschelite; P3 orthorhombic stick-like shaped crystals; 44 polyhedral crystals of carbonates.

pequeña (ver Figura 1). También se observo por SEM la presencia de algunos cristales ortorrómbicos en forma de bastón [ver Figura 5(b), P3]. La relación Si/Al de estos cristales es de 2,6 .

Adicionalmente, en la Figura 5(c), podemos observar que, en este caso, los cristales de zeolita no aparecen dentro de los poros o en las huellas dejadas por partículas de ceniza al reaccionar. Los cristales aparecen ocupando espacios grandes en el sistema, como si fueran un producto principal de la reacción. A pesar de que las causas de este fenómeno no están todavía claras, una posible explicación podría buscarse en el hecho de que la presencia de iones carbonato en la disolución activadora redunda en una menor concentración de iones $\mathrm{OH}^{-}$lo cual, a su vez, impone una notable ralentización del proceso de formación del gel de silicoaluminato alcalino. La lentitud en el desarrollo cinético de las reacciones favorecería la cristalización de zeolitas en vez de la consolidación del "precursor zeolítico". Son numerosos los trabajos publicados que sintetizan zeolitas (y no un material cementante) a partir de cenizas volantes en condiciones de alcalinidad más suaves $(20,21)$. Mientras que el precursor zeolítico con características cementantes necesita para su formación de condiciones mas enérgicas (muy elevada alcalinidad) $(1,10)$. En la Figura 5(a) también se observa la presencia de algunos cristales poliédricos que se corresponden con los carbonatos [ver Figura 5(c), P4].

Del análisis obtenido por EDX (ver Tabla 3) se ha deducido el valor promedio de la relación "Si/Al" en los geles de silicoaluminato formados. De los datos recogidos en dicha tabla es importante destacar que, para el caso concreto de los sistemas activados con compuestos de sodio, el aumento en el tiempo de curado térmico (desde 20 horas a 7 días) induce una importante modificación en la composición del gel prezeolítico; es decir, se enriquece en $\mathrm{Si}$ y se empobrece en Al. No obstante, como se muestra a continuación, no se percibe un efecto similar en el caso de los sistemas activados con compuestos de potasio. some crystals of orthorhombic stick-like shape was also observed in the SEM image [Figure 5(b), P3]. The Si/Al ratio of these crystals is 2.6 .

Additionally through the Fig. 5(c) we can observe that in this case the zeolitic crystals do not appear inside the pores or in the marks left by those ash particles that disappear after the reaction. They are to be found occupying large spaces in the system as if they were a main reaction product. Even though the causes of this phenomenon are still not clear, a possible explanation might be found in the fact that the presence of carbonate ions in the activator solution results in a lesser concentration of $\mathrm{OH}$ ions, which in turn imposes a notable slowing down of the alkaline aluminosilicate gel formation process. The slowness in kinetic development of the reactions would favour zeolite crystallization instead of the consolidation of "zeolite precursors". There are numerous published papers that synthesize zeolites (and not cementitious material) from fly ash in milder alkali conditions $(20,21)$. Whereas the formation of the zeolite precursor with cementitious characteristics requires more energetic conditions (very high alkalinity) $(1,10)$. Finally the presence of some polyhedral crystals corresponding to carbonates can also be observed [see Figure 5(c), P4].

From the EDX analysis (see Table 3) an averaged compositional ratio of "Si/Al" has been deduced for the alkaline aluminosilicate gel. From the information given in the above mentioned table, it is important to emphasize that for the specific case of systems activated with Sodium compounds, the increase in thermal curing time (from 20 hours to 7 days) induces an important change in the composition of prezeolitic gel; in other words it becomes enriched in Si and impoverished in Al. No similar effect is found in the case of systems activated with Potassium compounds. 
TABLA 3/ TABLE 3

Valor medio composicional de la relación "Si/Al" en los geles cementantes de aluminosilicato Averaged compositional ratios of "Si/Al" in the alkaline aluminosilicate gel binder

\begin{tabular}{|l|c|c|}
\hline & $\begin{array}{c}\text { Si/Al } \\
\left(20 \mathrm{~h} \text { at } 85^{\circ} \mathrm{C}\right)\end{array}$ & $\begin{array}{c}\mathrm{Si} / \mathrm{Al} \\
\left(7 \mathrm{~d} \text { at } 85^{\circ} \mathrm{C}\right)\end{array}$ \\
\hline $\begin{array}{l}\text { Sample } A \\
\text { Muestra A }\end{array}$ & 1.90 & 2.04 \\
\hline $\begin{array}{l}\text { Sample B } \\
\text { Muestra B }\end{array}$ & 1.97 & 2.26 \\
\hline $\begin{array}{l}\text { Sample C } \\
\text { Muestra C }\end{array}$ & 1.83 & 1.99 \\
\hline $\begin{array}{l}\text { Sample D } \\
\text { Muestra D }\end{array}$ & 1.65 & 1.73 \\
\hline $\begin{array}{l}\text { Sample E } \\
\text { Muestra E }\end{array}$ & 2.35 & 1.95 \\
\hline $\begin{array}{l}\text { Sample F } \\
\text { Muestra F }\end{array}$ & 1.98 & \\
\hline
\end{tabular}

\section{Materiales activados con potasio}

En la Figura 6 se muestran algunos detalles morfológicos y microestructurales que ponen de manifiesto las peculiaridades específicas de la activación alcalina de las cenizas volantes con compuestos de potasio. Generalmente hablando, durante las primeras horas de la reacción, cuando el potasio reacciona con el componente vítreo de la ceniza, los productos de la reacción permanecen ligados sobre las partículas originales de la ceniza (formando esferas). No se produce una dispersión del producto de reacción alrededor del sistema, y, por consiguiente, muchos de los huecos del sistema permanecen desocupados [en la Figura 6(a) y (c) puede verse la presencia de una cantidad relativamente alta de poros, así como de partículas de ceniza sin reaccionar].

En la Figura 6(b) se muestra un ejemplo representativo de la evolución microestructural que presentan las cenizas volantes activadas con la disolución $\boldsymbol{E}$, en la que hay un cierto contenido de silicatos solubles. En esta micrografía se pueden observar importantes diferencias morfológicas en la matriz desarrollada con respecto a las Figura 6(a) y (c) precisamente debido a la presencia en la disolución de los iones silicato. En este caso se observa una mayor compacidad de la matriz así como la formación de un material quasi-vítreo, similar al obtenido cuando el activador es una mezcla de hidróxido sódico y waterglass (ver Figura 4). La relación Si/Al en este gel es ligeramente superior al que se forma con la disolución B (ver Tabla 3) dado que, en este caso, la cantidad de iones silicato adicionados en la disolución es también ligeramente mayor (ver Tabla 1).

Finalmente, en la Figura 6(c) se muestran algunos aspectos microscópicos representativos de las cenizas activadas con la disolución $\boldsymbol{F}$. Si tenemos en cuenta que con las

\section{Potassium activated materials}

Some morphologic and microstructural details can be seen in Figure 6 that clearly show the specific peculiarities of the alkaline activation of fly ash with potassium compounds. Generally speaking, during the first hours of the reaction, when potassium interacts with the glassy component of the ash, the reaction products remain basically "bound" on the original (spherical shaped) ash particles; there is no dispersion of the product of reaction all around the system, and consequently many of the voids of the system remain unoccupied [the presence of a relatively high amount of pores as well as un-reacted fly ash particles can be seen in Figure 6(a) and Figure 6(c)].

Figure $6(b)$ provides a representative example of the microstructural evolution in fly ash activated with solution

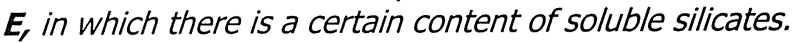
In this micrography important morphologic differences can be observed in the matrix developed with regard to Figure $5 a$ and $c$ and are precisely due to the presence of silicate ions in the solution. In this case greater compactness of the matrix is observed as well as the formation of a quasiglassy material similar to that obtained with activators made of mixtures of sodium hydroxide and waterglass, (see Figure 4). The Si/Al ratio in this gel is slightly higher than that formed by solution B (see Table 3) because in this case the amount of additional silicate ions in the solution is also slightly higher (see Table 1).

Finally, some typical microscopic aspects of fly ashes activated with solution $\boldsymbol{F}$ can be seen in Figure 6(c). If we bear in mind that, generally speaking, the extent of 

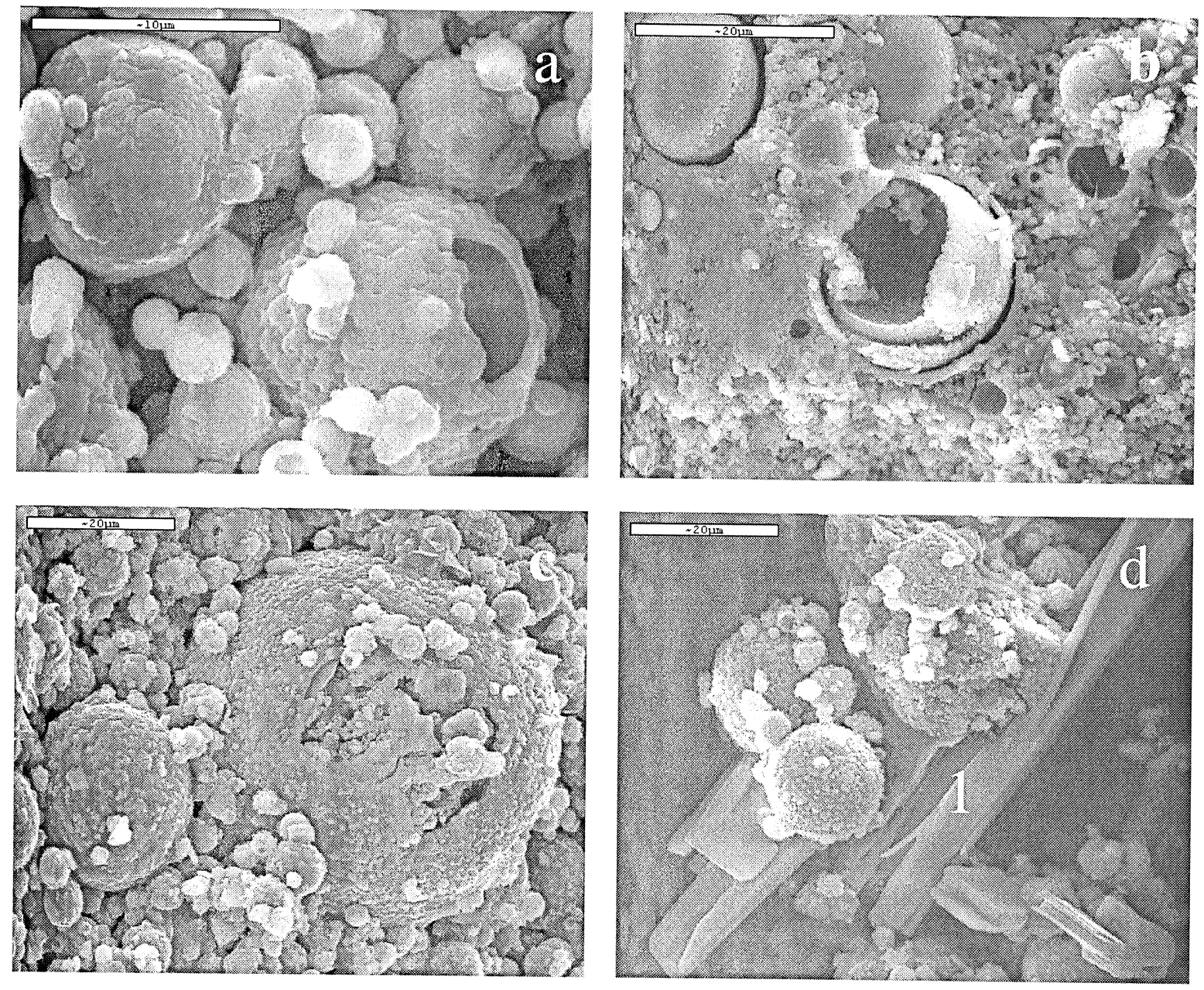

Figura 6.- Ceniza volante activada con sales potásicas: a) disolución $\mathrm{D}(\mathrm{KOH} 8.5 \mathrm{M}) 20 \mathrm{~h}$ a $85{ }^{\circ} \mathrm{C}$, b) disolución E (KOH $10 \mathrm{M}+15 \%$ silicato potásico) $20 \mathrm{~h}$ a $\left.85^{\circ} \mathrm{C} ; \mathrm{c}\right)$ y d) disolución $\mathrm{F}(\mathrm{KOH} 3.5 \mathrm{M}+10 \%$ de carbonato potásico en masa con respecto al contenido de ceniza) 20 h. y 7 días a $85^{\circ} \mathrm{C}$. 1 : carbonato potásico.

Figure 6. - Alkali activated fly ash with potassium salts: a) solution D (KOH $8.5 \mathrm{M}) 20$ hours at $85{ }^{\circ} \mathrm{C}$, b) solution $\mathrm{E}(\mathrm{KOH} 10 \mathrm{M}+15 \%$ potassium silicate) 20 hours at $85^{\circ} \mathrm{C}$ and C) and d) solution $\mathrm{F}(\mathrm{KOH} 3.5 \mathrm{M}+10 \%$ of potassium carbonate in mass with respect to the fly ash content) 20 hours and 7 days at $85^{\circ} \mathrm{C}$. 1: potassium carbonate.

sales potásicas, en general, el grado de desarrollo de la matriz es menor que con las sódicas (en iguales condiciones experimentales), en este caso, en el que se produce una cierta acidificación del medio (como consecuencia de la adición de carbonatos), se favorece la evolución del sistema hacia un estado "granular" en el que se identifican un gran número de partículas, parcialmente atacadas, que conservan la forma esférica original, en vez de la formación masiva del gel prezeolitico cementante. No obstante, el gel de aluminosilicato potásico que se forma presenta una relación Si/Al del mismo orden de magnitud al de casos anteriores (ver Tabla 3). Un hecho destacable en torno al sistema activado con la disolución $\mathrm{F}$ lo constituye la presencia de carbonatos y bicarbonatos potásicos, que pueden verse en la Figura 6(d). Sin embargo, no se observa la presencia de zeolitas, dado que en disoluciones de carbonatos el grado de cristalización de éstas es muy pequeño. the activation reactions development with potassium salts is less than with sodium salts (in equal experimental conditions), in the case in which certain acidification of the media is produced (as a result of adding carbonates) the system evolves into a "granular» state in which a great number of partially irresolute particles that preserve the original spherical shape can be identified (instead of a massive formation of cementitious prezeolitic gel). However the alkaline aluminosilicate gel formed has a Si/Al ratio of the same order of magnitude as in earlier cases (see Table 3). An outstanding fact concerning the system activated with solution $F$ is the presence of potassium carbonates and bicarbonates, as given in Figure $6(d)$. The presence of zeolites is not observed, however, as the extent of the crystallization is very small by using carbonate solutions as alkaline activators. 


\section{DISCUSIÓN}

En general, se admite que se desarrolla en varias etapas el proceso de síntesis de zeolitas a partir de silicatos alcalinos $(22,23)$. En la primera fase, el mineral de aluminosilicato es disuelto en la disolución alcalina, ello favorece la formación de diferentes precursores zeolíticos a partir de las especies disueltas; $y$, en la segunda fase, diferentes núcleos alcanzan un tamaño crítico y dan lugar al inicio del crecimiento del cristal.

En el caso particular de la activación de cenizas volantes en medios muy alcalinos, lo que se forma es un material cementoso con elevadas resistencias mecánicas. El proceso de reacción puede ser considerado similar al de la formación de zeolitas en el que la primera etapa podría dividirse, a su vez, en dos sub-etapas (15, 24): destrucción-coagulación y coagulación-condensación. Las principales diferencias entre los sistemas tradicionales de síntesis de zeolitas y los sistemas cementantes de activación alcalina son las diferentes condiciones experimentales empleadas. En el caso de la activación de cenizas volantes se trabaja con bajas relaciones "líquido/sólido" y muy altas concentraciones de $\mathrm{OH}^{-}$. Estas condiciones experimentales conducen a situaciones en las que el crecimiento de cristal a partir de los núcleos zeolíticos inicialmente formados (segunda fase) es sumamente lento $y$, por consiguiente, una matriz cementosa básicamente amorfa (gel de aluminosilicato o "precursor zeolítico") es preferentemente estabilizada. Sin embargo, también se detecta la presencia de pequeñas cantidades de zeolitas formando parte del material cementante. Su presencia, probablemente, es indicativa de que, desde un punto de vista termodinámico, las zeolitas cristalinas son las fases más estables hacia las cuales el sistema evolucionara con el tiempo.

El mecanismo que controla la reacción química que tiene lugar para que se forme el gel de silicoaluminato alcalino está inicialmente asociado a un proceso de disolución (la elevada concentración de iónes $\mathrm{OH}^{-}$en el medio rompe los enlaces covalentes $\mathrm{Si}-\mathrm{O}-\mathrm{Si}$, Si-O-Al y Al-O-Al presentes en la fase vítrea de la ceniza, y los iones silicio y aluminio pasan al medio formando grupos $\mathrm{Si}-\mathrm{OH}$ y $\mathrm{Al}-\mathrm{OH}$ ). Posteriormente, estas especies químicas condensan (forman enlaces $\mathrm{Si}-\mathrm{O}-\mathrm{Al}$ y $\mathrm{Si}-\mathrm{O}-\mathrm{Si}$ ) y dan lugar a la formación de un "precursor zeolítico", caracterizado por poseer una estructura tridimensional de corto alcance $(3,10,25)$.

En este proceso químico hay que destacar que el papel que juegan los cationes alcalinos que se incorporan al sistema es esencial dado que éstos actúan compensando y equilibrando el balance de carga eléctrica que descompensa la estructura por la sustitución de átomos de $\mathrm{Si}^{4+}$ por átomos de $\mathrm{Al}^{3+}$.

Ahora bien, los resultados de esta investigación demuestran que sodio y potasio no se comportan igual en lo que respecta al desarrollo microestructural de los materiales estudiados; lo cual coincide con los resultados observados por otros autores que han planteado investigaciones similares a la que aquí se describen, bien en el campo de los cementos alcalinos (26), bien en el campo de las zeolitas (27).

\section{DISCUSSION}

In general, it is admitted that several stages are produced during the synthesis of zeolites from alkaline leached silicates $(22,23)$. In the first stage, the aluminosilicate mineral is dissolved in the alkali solution, which favours the formation of different zeolite precursors from dissolved species; and in the second stage, different nuclei reach the critical size and the crystal growth starts.

The particular case of the activation of fly ashes in highly alkaline environments in order to produce cementitious materials with high mechanical strengths might be considered like a zeolite forming system in which the first stage could be divided into two sub-stages (5, 10): destruction-coagulation and coagulation-condensation. The main differences between traditional zeolitic systems and alkaline activated binding systems come from the differences existing in the experimental conditions used. In the case of the activation of fly ashes we work with low "liquid/solid" ratios and very high $\mathrm{OH}$ concentrations. These experimental conditions lead to a situation in which the crystal growth from the zeolitic nuclei formed (second stage) is extremely slow and therefore, an amorphous cementitious matrix (aluminosilicate gel or "zeolite precursor") is initially stabilized. However small amounts of zeolites are detected to form part of our cementitious material. Its presence is probably indicating that crystalline zeolites are the thermodinamically stable phases towards which the system should evolve with time.

The mechanism controlling the chemical reaction that takes place to produce alkaline aluminosilicate gel is initially associated with a dissolution process (the high concentration of $\mathrm{OH}$ ions in the media breaks the covalent Si-O-Si, Si-O-Al and Al-O-Al links present in the glassy phase of the ash, and the silicon and aluminium ions pass over to the media forming Si-OH and Al-OH groups). Later on these chemical species condense (forming Si-O-Al and $\mathrm{Si}-\mathrm{O}$-Si links) and they give rise to the formation of a «zeolite precursor» characterized by its short-range threedimensional structure $(3,10,25)$.

In this chemical process we should emphasize that the role played by the alkaline cations incorporated into the system is essential since they act by compensating and stabilizing the balance of the electrical charge that recompenses the substitution of $\mathrm{Si}^{4+}$ for $\mathrm{Al}^{3+}$ atoms in the structure.

However, the results of this research demonstrate that sodium and potassium do not behave in the same way with respect to the microstructural development of the materials being studied; this coincides with the results observed by other authors who have raised similar investigations to the one described here, whe in the field of alkaline cements (26) or in the field of zeolites (27). 
Paralelamente, los resultados de la presente investigación también han puesto de manifiesto que el anión que acompaña al álcali en la disolución activadora ejerce, igualmente, un efecto importante en el desarrollo de las reacciones que se dan en los sistemas estudiados $y$, consecuentemente, en las características mineralógicas y microestructurales de los materiales sintetizados. Sin embargo, y dado que el efecto de silicatos solubles y carbonatos ya fue objeto de discusión de un trabajo previo (14), la discusión del presente trabajo se centra en la comparación de sodio y potasio como elementos que participan y condicionan el desarrollo de la microestructura de las cenizas volantes activadas.

En este sentido, y dado que la primera etapa de la reacción está controlada por la capacidad del compuesto alcalino para disolver a la ceniza volante y producir pequeñas especies reactivas de silicatos y aluminatos, sería razonable pensar que, en el caso de los hidróxidos de sodio y potasio, fuera el $\mathrm{KOH}$ el que presentase una mayor actividad disolvente debido a su superior alcalinidad. Sin embargo, la realidad demuestra que es el $\mathrm{NaOH}$ el que posee mayor capacidad de liberación de monómeros de silicato y aluminato.

Al igual que Park et al. (27), nosotros pensamos que la diferencia en el tamaño del ión es un factor determinante que interviene en la cinética de las reacciones y que los cationes de sodio, por ser de menor tamaño que los de potasio, tienen una mejor aptitud a la zeolitización.

La Figura 7 es un ejemplo muy significativo que confirma la tesis, expuesta ya, que pone de manifiesto, una vez mas (28), la capacidad de los cationes $\mathrm{Na}^{+}$para estabilizar las "Sub-building units" (especialmente anillos de seis miembros) en las estructuras zeolíticas. También esta capacidad se incrementa con la concentración de $\mathrm{OH}^{-}$en el sistema y con el tiempo de curado térmico. Sin embargo, no se puede elaborar una figura similar a la Figura 7 con los datos de difracción de rayos $X$ procedentes de los
At the same time, the results of this research have also revealed that the anion that accompanies the alkali in the activator solution equally exerts an important effect on the development of reactions that occur in the systems being studied and consequently in the mineralogical and microstructural characteristics of synthesized materials. However, as the effect of soluble silicates and carbonates has already been the object of discussion in earlier work (14), the discussion of this paper concentrates on the comparison of sodium and potassium as elements that take part in and determine the development of the microstructure of activated fly ash.

In this respect and given that the first stage of the reaction is controlled by the aptitude of the alkaline compound to dissolve the solid fly ash network and to produce small reactive species of silicates and aluminates, it would be reasonable to think that in the case of sodium and potassium hydroxides, it should be $\mathrm{KOH}$ the compound showing greater dissolvent activity due to its higher level of alkalinity. Nevertheless, reality demonstrates that it is $\mathrm{NaOH}$ that possesses a greater capacity to liberate silicate and aluminate monomers.

Like Park et al. (27), we believe that the ion size difference is a determinant factor that intervenes in the kinetics of the reactions and that the sodium cations have better zeolitization capabilities because they are smaller than potassium cations.

Figure 7 is a very significant example that confirms the thesis put forward as it demonstrates once again (28) the capacity of the $\mathrm{Na}^{+}$cations to stabilize the sub-building units (especially six-membered rings) of zeolite frameworks. In addition this capacity increases with $\mathrm{OH}^{+}$ concentration in the system and also with the thermal curing time. However a figure similar to Figure 7 cannot be reproduced with $X$-ray diffraction data from systems activated with potassium (see Figure 1 , solutions D, E

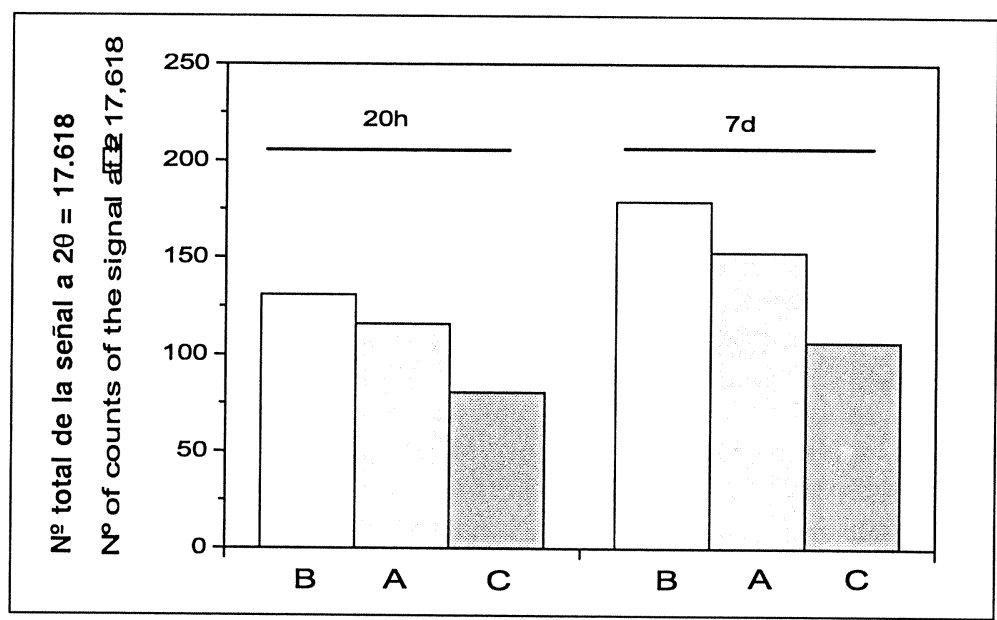

Figura 7.- Intensidad de difracción de los picos de rayos $X$ asociados a la presencia de herchelita respectivamente obtenida con las disoluciones $\mathrm{A}$, B y C. Izquierda $20 \mathrm{~h}$ a $85^{\circ} \mathrm{C}$; derecha 7 días a $85^{\circ} \mathrm{C}$.

Figure 7.- $X$-ray diffraction intensity of herschelite lines respectively obtained with solutions $A, B$ and C. Left 20 hours at $85{ }^{\circ} \mathrm{C}$; right 7 days at $85^{\circ} \mathrm{C}$. 

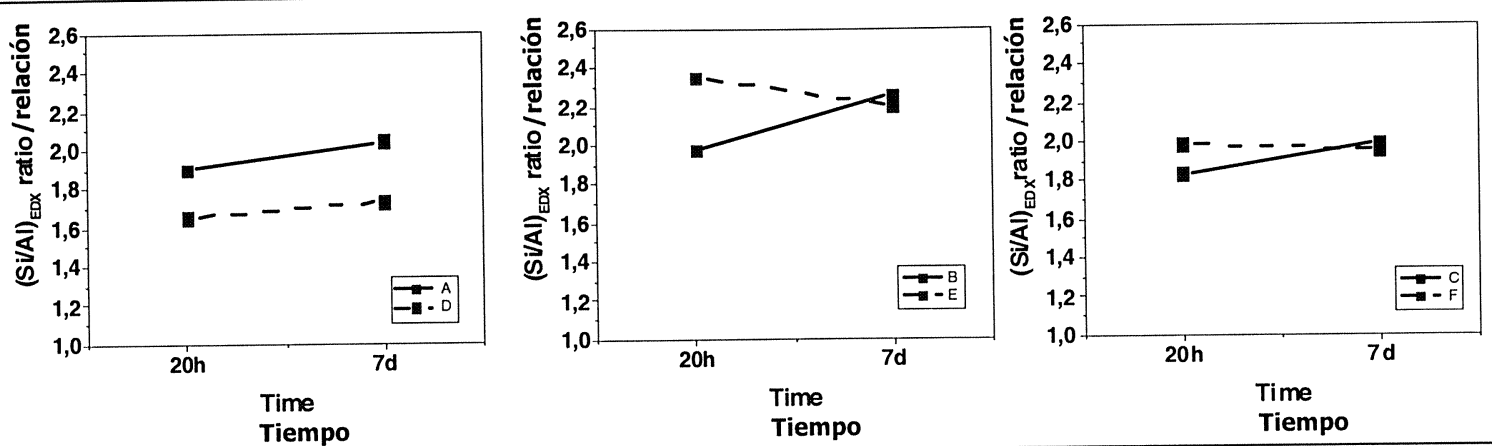

Figura 8.- Evolución en el tiempo de la relación Si/Al del precursor zeolítico. Efecto comparativo de las disoluciones de sodio frente a las de potasio.

Figure 8. - Evolution over time of the Si/Al ratio of the zeolite precursor. Comparative effect of sodium versus potassium solutions.

sistemas activados con potasio (ver Figura 1, disoluciones $D, E$ y $F$ ), porque las zeolitas que cristalizan en los sistemas activados con compuestos de potasio sólo cristalizan a nivel de trazas, con independencia de la concentración de iones hidroxilo presentes y con independencia, también, del tiempo de curado térmico. Además, la zeolita detectada en los sistemas de 20 horas de curado térmico (chabazite-K), no se detecta en ninguno de los sistemas de 7 días, lo que podría sugerir una cierta situación de inestabilidad composicional debido a la lentitud con la que se desarrollan estos sistemas.

Finalmente, la Figura 8 ratifica la idea principal de esta investigación según la cual el tipo de catión empleado en el proceso de activación de las cenizas volantes (sodio o potasio) juega un papel fundamental en el desarrollo cinético de las reacciones. Dicha figura muestra el paulatino enriquecimiento en silicio que, con el tiempo, sufre el gel prezeolítico en el caso de los sistemas activados con sodio y que ya fue observado en trabajos previos (10, 11). En el caso de los sistemas activados con potasio esta evolución no se manifiesta con tanta claridad.

\section{CONCLUSIONES}

De los resultados de la presente investigación se concluye que la concentración de $\mathrm{OH}^{-}$existente en las disoluciones alcalinas juega un papel esencial en la etapa de disolución de la sílice y la alúmina reactiva de las cenizas volantes. Los álcalis, sin embargo (sodio/potasio), ejercen un papel regulador de la cinética de las reacciones. Así, el $\mathrm{K}^{+}$, por su superior tamaño respecto al sodio, induce una menor velocidad de cristalización de las zeolitas y, por lo tanto, una más lenta evolución del gel prezeolítico, lo que a su vez explica que la activación de las cenizas volantes llevadas a cabo con compuestos de potasio generen matrices cementantes con estructuras más porosas $y$, por lo tanto, menos resistentes desde el punto de vista mecánico.

\section{AGRADECIMIENTOS}

Este estudio fue financiado por la Dirección General de Investigación Científica y Técnica, MEC (proyecto BIA2004-04835). A. Fernández-Jiménez también agradece al CSIC la financiación del contrato I3P ((REF. 13PPC2004L) co-financiado por el Fondo Social Europeo. and $F$ ), because zeolites that crystallize in systems activated with potassium compounds crystallize at trace level; regardless not only of the hydroxyl ion concentration present but also the thermal curing time. In addition, the zeolite detected in the 20-hour thermally cured systems (chabazite), is not detected in any of the 7-day systems, which might suggest a certain situation of compositional instability due to the slowness with which these systems develop.

Finally, Figure 8 ratifies the main idea of this investigation, according to which the type of cation used in the fly ash activation process (sodium or potassium) plays a fundamental role in the kinetic development of the reactions. This figure shows the gradual enrichment in silicon that, over time, is suffered by the prezeolitic gel in the case of systems activated with sodium (and that was previously observed in earlier works $(10,11)$. In the case of the systems activated with potassium, this evolution is not demonstrated quite so clearly.

\section{CONCLUSIONS}

From the results of this investigation it can be concluded that the $\mathrm{OH}$ concentration existing in alkaline solutions plays a fundamental role in the initial dissolution step of silica and alumina from the fly ash. However the alkalis (sodium / potassium) perform a regulatory role in reaction kinetics. Therefore, due to the larger size of $\mathrm{K}^{+}$compared to $\mathrm{Na}^{+}$, it induces a lower crystallization speed of the zeolites and hence a slower development of prezeolitic gel. This in turn explains that the activation of fly ash carried out with Potassium compounds generate cementitious matrixes with more porous structures and therefore are less resistant from a mechanical point of view.

\section{ACKNOWLEDGEMENTS}

This study was funded by the Directorate General of Scientific and Technical Research, MEC (project BIA200404835) A. Fernandez-Jimenez thanks the to the CSIC for the I3P contract ((REF, 13P-PC2004L) co-financed by the European Social Fund. 


\section{BIBLIOGRAFÍA}

(1) A. Palomo, M-W. Grutzeck, M. T. Blanco, «Alkali-activated fly ashes a cement for the future», Cem. Concr. Res., Vol. 29 (1999), pp. $1323-1329$.

(2) A. Fernández-Jiménez, A. Palomo, «Alkali-activated fly ashes: properties and characteristics». 11th International Congress on the (3) V. D.

(3) V. D. Glukhovskiy, Soil silicates. Gosstroy publsh, Kiev, 1959. (In Russian.)

(4) J. G. S. van Jaarsveld, J. S. J. van Deventer, G. C. Lukey, «The effect of composition and temperature on the properties of fly ash and kaolinite-based geopolymers», Chemical Engineering Journal, Vol. 89 (2002), pp. 63-73.

(5) P. V. Krivenko, «Alkaline Cements». Proceed. First Intern. Conf. Alkaline cements and Concretes, Kiev, Vipol publish (1994), pp. 11-129. (6) D. Hardjito, S. E. Wallah, D. M. J. Sumajouw, B. V. Rangan, «Brief Review of Development of geopolymer Concrete». 8th CANMET/ACI International Conference on fly ash, silica fume, slag and natural pozzolans in concrete. Las Vegas (USA), 2004.

(7) A. Palomo, A. Fernández-Jiménez, C. López-Hombrados, J. L. Lleyda, «Precast elements made of alkali-activated fly ash concrete». 8th CANMET/ACI International Conference on fly ash, silica fume, slag and natural pozzolans in concrete, Las Vegas (USA), Supplementary
Volume (2004), pp. 545-558.

(8) A. Palomo, P. F. G. Banfill, A. Fernández-Jiménez, D. S. Swift, «Properties of alkali activated fly ashes determined from rheological
measurements», Adv. Cem. Res, Vol 17 (2005) measurements», Adv. Cem. Res., Vol. 17 (2005), pp. 143-151.

(9) A. Fernández-Jiménez, A. Palomo, C. López-Hombrados, «Engineering properties of alkali activated fly ash concrete», ACI Mat. Journal (in press, 2006).

(10) A. Palomo, S. Alonso, A. Fernández-Jiménez, I. Sobrados J. Sanz, «Alkaline activation of fly ashes. A ${ }^{29}$ Si NMR study of the reaction products», J. Am. Ceramic. Soc., 87 (6) (2004), pp. 1141-1145.

(11) A. Fernández-Jiménez, A. Palomo, «Alkali activated fly ashes. Structural studies through Mid-Infrared Spectroscopy», Microporous \& (12) A. Palomo, A. Fernández-Jiménez, «Microstural development of alkali-activated fly ash cement. A descriptive model», Cem. Concr.
Res., 35 (2005), pp. 1204-1209. (13) A. Palomo, A. Fernández-Jiménez, M. Criado, «Geopolymers: same basic chemistry, different microstructures», Mater. Construcc., Vol.
54 (2004), pp. 77-91.

(14) A. Fernández-Jiménez, A. Palomo, «Microstructure of alkali activated fly ash mortars: effect of the activator», Cem. Concr. Res., 35 (2005), pp. 1984-2054.

(15) A. Fernández-Jiménez, A. Palomo, «Characterisation of fly ashes. Potential reactivity as alkaline cements», Fuel., 82(2003), pp.
2259-2265.

(16) M. Criado, Inmovilización de residuos tóxicos en matrices de cenizas volantes activadas alcalinamente. Tesis doctoral, Universidad Autónoma de Madrid (España) (in progress).

(17) M. Criado, A. Palomo, A. Fernández-Jiménez, «Alkali activation of fly ashes. Effect of curing conditions on the nature of the reaction products», Fuel., 84 (2005), pp. 2048-2054. (18) Norihio Murayama, Hideki Yamamoto, Junji Shibata, «Mechanism of zeolite synthesis from coal fly ash by alkali hydrothermal reaction»,
Int. J. Miner. Process, Vol. 64 (2002), pp. 1-17.

(19) C. Yip Ka-Bik, The role of calcium in geopolymerisation. Doctoral thesis, University of Melbourne (Australia).

(20) X. Querol, N. Moreno, J. C. Umaña, A. Alastuey, E. Hernández, A. López-Soler, F. Plana, «Sintesis of zeolites from coal fly ash: on overview», Inter. National J. of Coal Geology, 50 (2002), pp. 413-423.

(21) M. Grutzeck, K. Atephen, M. DiCola, «Zeolite formation in alkali-activated cementitious systems», Cem. Concr. Res., Vol. 34, no 6 (2004), pp. 949-955.

(22) R. Aiello, C. Collela, R. Sersale, «Molecular sieves; Advances in chemistry series 101», Am. Che. Soc., Washington D. C. (1971), p. 102.

(23) E. M. Flanigen, «Molecular sieves; Advances in chemistry serjes», Am. Che. Soc., 121, Washington D. C. (1973), p. 119.

(24) P. V. Krivenko, «Alkali cements». First International Conference of Alkaline Cements and Concretes, Ukraine, Kiev (1994), pp. 12-129.

(25) J. S. J. van Deventer, Hua Xu, «The geopolymerisation of alumino-silicate minerals». Int. J. Miner. Process, 59 (2000), pp. $247-266$.

(26) A Buchwald, Ch. Kaps, M. Hohman, «Alkali-activated binder and pozzolan cement binder-compete binder reaction or Two sides of the same story». Proceedings of the 11th International Congress on the Chemistry of Cement (ICCC), Durban, South Africa (2003),

(27) Man Park, Choong Lyeal Choi, Woo Taik Lim, Myung Chul Kim, Jyung Choi and Nam Ho Heo, «Molten-salt method for the synthesis of zeolite molten-salt system», Microporous and Mesoporous Materials, Vol. 37 (2000), pp. 81-89.

(28) D. W. Breck, Zeolite Molecular Sieves, Ed. Malabar (Florida), Robert E. Krieger Publishing Company, 1984. ISBN 0-89874-648-5. 